\title{
Non-Western Contexts: The Invisible Half
}

Aliakbar Jafari (University of Strathclyde, UK), Fuat Furat (University of Texas-Pan American, USA), Ahmet Süerdem (Istanbul Bilgi University, Turkey), Søren Askegaard (University of Southern Denmark, Denmark), \& Daniele Dalli (University of Pisa, Italy)

\section{In: Marketing Theory, 12(1), 3-12.}

Consumption is an inherently cultural activity and actual evidence about it is strongly influenced by both the cultural orientation of scholars and the cultural settings in which such evidence has been studied. A long tradition in consumption studies has developed in the Western, economically developed, societies by scholars whose backgrounds are rooted in the Western tradition of thought. Apart from some exceptions, some of which will be reviewed hereafter, consumption studies generally present this sort of Western bias in epistemological and ontological terms. The purpose of this special issue is that of highlighting the importance and the need for considering theoretical and ideological approaches to the studies of consumption that do not necessarily belong to the Western tradition. As such, non-Western contexts that have been observed from a Western perspective need to be reconsidered under a different light. In so doing, scholars need to interpret consumption in the light of theoretical categories and constructs that are compatible with the cultural context under scrutiny (Venkatesh, 1995; Meamber and Venkatesh, 2000).

In this vein, Ilmonen's (1985) 'What Consumer Research Has Forgotten' could mark the beginning of a serious debate in consumer research. By rejecting generalisations about consumer culture and attributing certain characteristics to developed capitalistic countries, he made a vivid distinction between economically developed (Western) countries and the rest of the world (economically less-developed, mostly non-Western societies). The implication of Ilmonen's argument was that since "consumption does not take place in an economic and social vacuum" and consequently should be "viewed in its cultural context" (p.415), the theories developed in certain societies could not be simply generalised and applied to other contexts. One pioneering work in terms of demonstrating the limitations of cultural contextuality of standard Western models in marketing and consumer research was Arnould's (1989) analysis of processes of diffusion among the Hausa in the Republic of Niger. In this context, Arnould underlined the intertwined social systems of logics of competing models, including a traditional pre-market model, the Western market-based model and an Islamicnationalist model. Ger and Belk were other pioneers of investigating non-Western contexts. Underlining the tendency of the earliest research in non-Western consumer culture (e.g., Belk, 1988; Joy and Wallendorf, 1995) to consider these mere dysfunctional imitations of global (Western) consumer culture, they made an explicit call for conducting 'glocal' consumer research through their analysis of globalisation of consumer culture (Ger, 1995a and b; Ger and Belk, 1996). Significantly, in the same period of time, the edited volume on 'Marketing in a Multicultural World' (Costa and Bamossy, 1995) contained a chapter introducing the concept of 'ethnoconsumerism', calling for explicitly locally contextualised approaches for studying world consumer cultures and markets (Venkatesh, 1995). Since then, and due to its ever-increasing importance, conducting global consumer research has been deemed critical by many scholars. Steenkamp (2005) and Steenkamp and Burgess (2002), Laros and Steenkamp (2004) contend that the further advancement of consumer research requires us to test the validity of our theories - that have been generated in the context of 
Western and economically developed countries - in non-Western and economically less developed contexts. Similarly, Arnould and Thompson (2005), Belk et al. (2003), and Coulter et al. (2003) call for studying the manifestations of consumer culture in developing countries. Conversely, Ger (2005), Yazıcıoğlu and Firat (2007), Dalli et al. (2010), Jafari and Goulding (2008, 2010, forthcoming), Jafari et al. (2010), and Jafari (2011) call for more exploratory research in non-Western societies and contexts which "are made complex by the existence of multiple, competing, and contested cultures and 'orders"' (Yazıcıoglu and Firat, 2007, p. 115). The same theme has been recently emphasised by Romani et al. (2009), Jafari (2009), and Jafari et al. (2011) at the $5^{\text {th }}$ and $6^{\text {th }}$ Workshops on Interpretive Consumer Research in Milan and Odense. Yet, despite its significance, this issue has remained merely at the level of 'call for further investigation in non-Western contexts' in conference papers and journal articles.

This special edition addresses this timely topic and reflects the outcomes of "The International Workshop on Enhancing the Status of Consumer Research in Non-Western Contexts' held at the University of Strathclyde in July 2010. The major objective of this workshop was to probe the enhancement of consumer research by providing evidence and theoretical inspiration from non-Western contexts for a more reliable and inclusive body of knowledge within primarily consumer research and ultimately marketing. The workshop sought to create a platform for consumer culture researchers to exchange ideas and discuss the possibilities of encouraging non-Western researchers to introduce the less articulated, and sometime hidden, body of knowledge from their own contexts into the consumer culture debates.

In so doing, the intention has not been to polarise the world into Western and non-Western contexts as these are not monolithic concepts, and creating rigid boundaries between the two will not lead us anywhere. As many theorists, including Immanuel Wallerstein and Andre Gunder Frank, have well documented, insisting on a distinct separation of the world into developed vs. underdeveloped, Western vs. non-Western is at best illusory. History shows that the world has long been well interconnected into a world-system and a set of (inter)dependencies as a result of which the economic 'successes' of the West are tightly connected to blockages in the 'development' efforts of non-Western societies. Furthermore, there is no clear definition for these terms. Throughout history, and long before international geopolitical borders were created between countries, human societies had been exchanging ideas and practices in different areas of social life (Frank and Gills, 1993; Wolf, 1992). Hence, by Western and non-Western contexts we do not mean two separate clusters of culturally homogenous and geographically concentrated entities. Rather, we use these terms to acknowledge a diversity of historical, socio-cultural, economic, ideological, and political factors that have driven socio-economic developments and knowledge generation in different human societies. We also acknowledge that defining the scope of the West and non-West is subjective and time and discipline-bound. However, for the sake of our discussion in this manuscript, we have to attribute some characteristics to the Western world which are commonly used by social scientists. These common characteristics include but are not limited to: post-Renaissance scientific development, Enlightenment-based modernity, liberal democracy as the dominant political system, high income per capita as economic prosperity, and developed urban and technological infrastructure.

All of these characteristics had traditionally empowered the West in terms of knowledge production in different areas of scholarship. Yet, with the rise of new economies in the East, 
the equation of knowledge production in the world is shifting from the Western world to the Eastern hemisphere (Madhubani, 2009; UNESCO Science Report, 2010; Science Metrix, 2010). Interestingly, whilst these reports indicate that the shift is happening in pure and applied sciences and technological research, there is little sign for the drastic progress of social sciences in non-Western societies. In other words, within the realm of social sciences, knowledge production is still dominated by Western scholars. First and foremost, social sciences tend not to be of highest priority in developing contexts, as we will elaborate later. But there may be at least two different reasons to do with the structure of the disciplines rather than to the lack of scholarly work existing in non-Western contexts. One is the little attention by dominating scholars and scholarly media (journals and book publishers) to work coming from non-Western contexts. Second is the dominance of Western languages, specifically English, in the dominant media, which results in works in other languages to be unheard or not able to be understood by Western scholars.

Like many other disciplines within the broad area of social sciences (e.g., anthropology, psychology, sociology, etc.), consumer research is also highly navigated by scholars from the West. This, however, does not mean that consumer research is devoted to studying Western contexts only. As evident from the ever-increasing number of regional conferences (e.g., Asia-Pacific and Latin American conferences of the Association for Consumer Research) and non-Western students' enrolment in doctoral programmes at Western universities, there are many more researchers (from non-Western countries) who are entering the field and enriching it by their colourful contributions. The increase of collaboration among Western and non-Western scholars on consumer research projects is also bringing more insights into a deeper understanding of multiple dynamics associated with consumer behaviour in different parts of the world. Nowadays, almost all national and international conferences in marketing have special tracks devoted to consumer behaviour in emerging markets. All these practices indicate the ever-increasing importance of consumer research.

Yet, given the low number of publications on consumer research in non-Western contexts, it seems that our current knowledge in these societies has a long way to go to flourish. More specifically, and in the domain of consumer culture research, this gap is even further widened by the fact that consumer culture in such contexts is largely interpreted with reference to the 'grand narratives' of Western scholars (e.g., Foucault, Mafessoli, Bourdieu, Deleuze, Baudrillard, Nietzsche, Durkheim, Derrida, etc.). Therefore, from an ontological perspective, it seems that our existing knowledge about non-Western societies relies heavily on the 'theoretical structures' that are 'constructed' by Western philosophy as a set of ideas, beliefs, and practices (Said, 1978).

It is worth mentioning that some (see, for example, Kernan, 2002) may rightly argue that consumer research's overemphasis on consumer culture may distract us from acknowledging the fact that many people in less economically developed societies have not experienced consumer culture in the same way as Western, economically developed, societies have. Similarly, a sizeable part of the world population (both in Western and non-Western societies) may reject or resist the dominant market-generated ideology of consumer culture. Yet, the reality - and this is evident from the emerging results of ongoing research in different parts of the world - is that consumer culture has started to become a prevailing feature in modern society (Slater, 1997; Lury, 1996; Firat and Venkatesh, 1995; McCracken, 1988; Zukin and Maguire, 2004). One interesting point to observe here is that even those who do not approve of the dominant ideology of consumer culture (e.g., materialism) use different 
patterns of consumption to express their resistance or objection to this ideology. For instance, research on consumer activism (Kozinets and Handelman, 2004; Hollenbeck and Zinkhan, 2006; Cova and Dalli, 2009) implies that these people paradoxically become part of the consumer society. That is, they themselves form new segments of consumers that eventually become targets for marketers (e.g., green marketing). The market is therefore not necessarily something to be abandoned by critical consumers but used in order to create and promote particular social relations and practices considered fair and sustainable (Arnould, 2007). Therefore, in spite of the varying arguments for and against the dominance of consumer culture in contemporary society, consumer researchers need to be precisely sensitive to the multiple dynamics that shape varying consumption discourses in different societies. To be more specific, since the development of consumer culture is historical and contextual, its nature and dynamics in each society should be studied not only against the socio-cultural, historical, political, and economic background of a given context (Western or non-Western) but also with reference to the philosophical and epistemological viewpoints that analyse and interpret cultural practices of that society from within that culture.

Having discussed the importance of adopting local approaches to researching consumer culture, amongst many potential reasons, we would associate the scarcity of knowledge on consumer culture in non-Western societies to a series of key factors that follow:

Firstly, there are concerns over methodological orientations. Although interpretivism has now become a well-trodden path within consumer research (Hogg and Maclaran, 2008; Cova and Elliott, 2008), our field still is dominated by mainstream positivistic researchers who are interested in analysing consumers as cognitive agents. With their often behavioural methods, many positivist scholars in our field insist that replicating knowledge is paramount. The problem here is not the choice of methodological positions. Consumer research embraces methodological pluralism (Hogg and Maclaran, 2008) as it "neither necessitates fidelity to any one methodological orientation nor does it canonise a qualitative-quantitative divide" (Arnould and Thompson, 2005, p.870). Research methods are only 'means' and not 'ends' in themselves (Sandelowski, 1994) and the primary requirement of research within social sciences should be devotion to the phenomena under study, not to any set of methodological standards (Atkinson and Hamersley, 1995; Goulding, 1999). However, positivistic enquiries within consumer research often overlook a diversity of socio-cultural, economic, ideological, and political dynamics (specifically at a macro level) that underpin people's ever-changing consumption practices in different contexts (Arnould and Thompson, 2005; Arnould, 2002; Thompson and Haytko, 1997; Varman, and Saha, 2009; Jafari and Goulding, 2008; 2010; forthcoming; Jafari et al., 2010). Similarly, positivistic research often generates knowledge with a high reliance on testing the theories that have been developed mostly in Western contexts (Varman and Saha, 2009; Jafari, 2011). One consequence of the focus on current theories and facts is that current conditions and relationships are canonised and calcified, reinforcing the maintenance of 'what is' rather than being able to recognise the total spectrum of possibilities along with actualities. In effect, this is a consequence that emphasises the ideological tendencies in the exercise of science (Firat, 1985).

Secondly, a majority of non-Western societies are currently experiencing development programmes which necessitate prioritisation of certain research agendas (e.g., technological, engineering, health). As a result, amongst other social scientists, consumer researchers have limited financial resources and institutional support to produce knowledge. For instance, they do not have access to the myriad of books and journal articles researchers in Western 
contexts do. Neither do they have the sufficient academic freedom to choose their favourite research topics. Similarly, as a result of marginal conference budgeting, these scholars are deprived of attending international and global conferences in which they can network with peers. Consequently, they remain invisible in international academic spheres. This invisibility also deprives them of chairing seminar and conference sessions and sitting on editorial and review boards of journals and other publication outlets.

Thirdly, there is the issue of language, as earlier mentioned. Whilst researchers in Western contexts have the privilege of mastering the English language as the prime medium of international communication for publication, researchers in non-Western societies often have difficulties in disseminating their thoughts and research in English. This is of course a handicap encountered by all research not being native English speakers, but it is accentuated by the relatively weak schooling systems in many non-Western countries. Consequently, it is not difficult to imagine how their submissions to journals and other media get rejected solely on the basis of language use and tone, which is different due to cultural differences. Although lip service is often given to diversity, there is little tolerance of diversity when it comes to these differences. Quite often, they have to publish their works in languages other than English in their local journals and books which are rarely read by peers in international domain.

Fourthly, due to international political inequalities, researchers in non-Western societies are often paralysed in their own countries with little freedom to travel to other countries. For instance, researchers from Asia or Africa may have to undergo frustrating visa application processes to attend seminars/conferences in Western countries where most major academic conferences in consumer research and marketing are held. Compare this with Western scholars for whom the world is like home; what they need to do is to go to the airport and catch their flight to their destination.

Last but not least, as Kernan (2002) reminds us, "consumer research is a western phenomenon. It was born in the West, nurtured here, and has become sophisticated in this part of the world." In a special issue of Marketing Theory, it might be appropriate to notice that this is also true for marketing, at least as a modern and scientised praxis. In many nonWestern societies, marketing and consumer research largely remain less trodden paths. Additionally, consumption tends to be studied from different perspectives in non-Western contexts. Compared to the majority of Western universities in which consumer researchers are often nested in business schools and schools of management, those non-Western scholars whose research relates to issues of consumption and consumer culture are often affiliated with departments of sociology or anthropology. These scholars attend their own disciplinary conferences and publish their works in their own languages in their local disciplinary outlets. Their voices are therefore rarely heard and reflected in consumer research debates.

\section{Final remarks}

As researchers, we cannot, in the long term, afford missing out on the many realities that exist in human societies. People, or what in our academic tradition we have been accustomed to call 'consumers', live differently in different parts of the world. Whether in the busy shopping malls of Tokyo or Los Angeles or in a corner shop in Ulaanbaatar or Banjul, people's participation in market activities and their consumption practices shape their everyday life realities, the realities that are ultimately geared towards 'organising' their 
'lives' (Frrat and Dholakia, 1998). As marketing academics, we should therefore endeavour to understand how these 'real' people's consumption practices are (re)shaped over time. Similarly, our knowledge of these people's everyday life realities (including their consumption practices) should remain dynamic. This is not simply an academic task; it is a human responsibility. As Kernan (2002) reminds us, a large population of the world - who do not live in the West and whose views have not been taken into consideration in our theory building practices - deserve more respect.

Effective building of theory in the marketing discipline requires us to broaden our perspective to include all types of people who happen to participate in market activities as consumers. As we have elaborated in this manuscript, our existing knowledge of consumer culture generally relies on what we know about Western societies or with reference to what Western thought has made sense of in non-Western societies. Therefore, it is time that we seriously thought about how to resolve this knowledge gap issue in our discipline. This is a responsibility for all individuals and institutions whose professional practices influence generation and operationalisation of knowledge in marketing and other areas of social science.

\section{Contributions in this special issue}

All five papers in this special edition represent research on consumer culture in non-Western contexts. The first paper 'Approaching Non-western Consumer Cultures from a Historical Perspective: The Case of Early Modern Ottoman Consumer Culture' by Eminegül Karababa discusses the formation of consumer culture during the Ottoman Empire. Karababa demonstrates how alternative historical trajectories in the early modern period helped shape multiple consumer cultures. She contends that the development of consumer culture cannot be linked to a single Western trajectory of modernisation. In her paper, Karababa explains how interactions between different institutions (e.g., religion and market) paved the way for the emergence of exuberant consumer cultures. Karababa's historical approach to understanding consumer culture is important. As Tadajewski (2009) and Tadajewski and Saren (2008) also emphasise, the majority of misunderstandings in the field of marketing are rooted in 'ahistorical' approaches to different phenomena in marketing.

The second paper 'Practising $Q i$ and Consuming $K i$ : Folk Epistemology and Consumption Rituals in Japan', by Yuko Minowa, also takes a historical approach. Minowa discusses consumer knowledge in the context of consumption rituals in Japan. As the author contends, studying the development of local knowledge is imperative to knowledge generation in consumer research. Unlike prior research which tended to treat knowledge projects and consumption rituals as sequential conceptions, Minowa depicts folk epistemology as a study of commonsense knowledge and internalised beliefs of ordinary people. The paper proposes a model of transcendental consumption rituals, underpinned by cultural pragmatics and ontological liquidity. This entails a holistic approach to consumer rituals, synthesising both synchronic and diachronic aspects of the rituals. The author demonstrates how metaphors in language and tacit knowledge influence folk epistemology of consumption rituals. She shows the explanatory power of ontological viscosity and the spiritual centre of gravity in understanding the dynamism of consumer rituals in a relatively monolithic culture.

The third paper 'Global Yoga: Re-appropriation in the Indian Consumptionscape', is written by Søren Askegaard and Giana Eckhardt. In the context of global cultural flow, this paper discusses the re-appropriation of cultural practices in their places of origin after a process of 
sanctioning in the Western breeding ground of consumer culture production. The authors explore how the crossing and re-crossing of boundaries has fundamentally transformed the practices and ideas behind local consumption of Yoga in India. Askegaard and Eckhardt uncover six ways in which middle class yoga consumers in India interpret global yoga as it becomes a fashionable practice: yoga as a resource management technique, yoga as a health practice, yoga as a marketing phenomenon, global yoga, global yoga as cultural domination, and yoga as national heritage. This paper explicitly demonstrates the fallacies that will come from operating with a very strict dichotomy separating categorically the Western from the non-Western.

The fourth paper 'An Analysis of Material Consumption Culture in the Muslim World', by Aliakbar Jafari and Ahmet Süerdem, examines the notion of material consumption culture in Muslim societies. The authors differentiate between institutionalised religion and religion as culture. They contest the Orientalist portrayal of Islam as a fanatic ideology opposed to Western Modernity's features of secularism, individualism, and pluralism. Jafari and Süerdem argue that such qualities are embedded within Islam. They demonstrate that in their everyday life consumption practices, Muslims (re)interpret religious guidelines in different ways and refer to Islam, as a transcendental set of guidelines, to make better sense of their cultural practices in different ways. The authors criticise the clichéd discussions of Islam in binary oppositions of Islam vs. the West/Modernity. The authors precisely demonstrate the capability if ethnoconsumerism, as a powerful approach, in studying consumer culture. They stress that understanding a variety of consumption practices in contemporary Muslim societies requires that these practices be investigated from the lens of insiders and with reference to the historical dynamics that have changed Muslims' interpretations of Islam.

The final paper 'Exogamous Weddings and Fashion in a Rising Consumer Culture: Kabyle Minority Dynamics of Structure and Agency' presents Nacima Ourahmoune and Nil Özçağlar-Toulouse's examination of the intersection between fashion consumption, gender and the context of wedding ceremonies in contemporary Algeria. The authors investigate the role of fashion in consumers' identity construction amongst the Kabyles, a Western minority living in an Arabo-Islamic country. In their paper, the authors challenge the common notion of adopting fashion as a differentiation strategy and demonstrate how, due to power relations (gender, class and ethnicity), women adopt fashion to conform to their collective identities. Ourahmoune and Özçağlar-Toulouse's paper therefore can invite us to rethink our existing, and sometimes exaggerative, knowledge on how consumer culture accelerates individualism in non-Western contexts.

\section{References}

Arnould, E. J. (1989) 'Toward a Broadened Theory of Preference Formation and the Diffusion of Innovations: Cases from Zinder Province, Niger Republic', Journal of Consumer Research, 16 (2): 239-267.

Arnould, EJ. (2002) 'The Paradoxical Presence and Absence of Consumer Culture in a Third World Context', Advances in Consumer Research, 29 (1): 464-465.

Arnould, E.J. (2007) 'Should Consumer Citizens Escape the Market?', The Annals of the American Academy of Political and Social Science, 611 (1): 96-111.

Arnould, E.J. and Thompson, C.J. (2005) 'Consumer Culture Theory: Twenty Years of Research', Journal of Consumer Research, 31 (4): 868-83.

Atkinson, P. and Hammersley, M. (1995) Ethnography, $2^{\text {nd }}$ Ed. London: Routledge. 
Belk, R.W. (1988) 'Third World Consumer Culture', in E. Kumku and A.F. Firat (eds). Marketing and Development: Towards Broader Dimensions, pp. 103-27. Greenwich, CT: JAI Press.

Belk, R.W. (1995) The Rise of Consumer Society. London: Routledge.

Belk, R.W., Ger, G. and Askegaard, S. (2003) 'The Fire of Desire: A Multi-Site Inquiry into Consumer Passion', Journal of Consumer Research, 30 (3): 326-52.

Costa, Janeen A. and G. Bamossy (eds.) (1995) Marketing in a Multicultural World. Ethnicity, Nationalism and Cultural Identity. Thousand Oaks, CA: Sage Publications.

Coulter, R. A., Price, L.L. and Feick, L. (2003) 'The Origin of Involvement and Brand Commitment: Insights from Postsocialist Central Europe', Journal of Consumer Research, 30 (2): 170-83.

Cova, B. and Elliott, R. (2008) 'Everything you always wanted to know about interpretive consumer research but were afraid to ask', Qualitative Market Research: an International Journal, 11 (2): 121-129.

Cova, B. and Dalli, D. (2009) 'Working consumers: the next step in marketing theory?', Marketing Theory, 9 (3): 315-339.

Dalli, D., Romani, S. and Sadeh, H. (2010) 'West Bank consumer - brand relationships. Nonwestern grounded theory?', Finanza, Marketing, Produzione, 27 (4): 48-64.

Firat, A.F. (1985) 'Ideology vs. Science in Marketing', in N. Dholakia and J. Arndt (eds.), Greenwich Changing the Course of Marketing: Alternative Paradigms for Widening Marketing Theory, pp. 135-146. Greenwich, CT; JAI Press.

Firat, A.F. and Dholakia, N. (1998) Consuming People. From Political Economy to Theatres of Consumption. Routledge, London.

Firat, A.F. and Venkatesh, A. (1995) 'Liberatory Postmodernism and the Reenchantment of Consumption', Journal of Consumer Research, 22 (3): 239-67.

Folkes, V. (2002) Seeking Knowledge in Our Favorite Spots. http://www.acrnews.org/WINTR-01/PRS.html.

Frank, A.G. and Gills, B.K. (1993) The World system: five hundred years or five thousand years? London: Routledge.

Ger, G. (1995a) 'Consumer Culture and Development Contexts', Proceedings of the Fifth International Conference on Marketing and Development, International Society for Marketing and Development: 11-17

Ger, G. (2005b) Reflections on Consumer Culture Research, Presentation at ACR Doctoral Consortium, Bilkent University. Available from http://www.acrwebsite.org/fop/index.asp?itemID=108.

Ger, G. and Belk, R.W. (1996) 'I'd Like to Buy the World a Coke: Consumptionscapes of a Less Affluent World', Journal of Consumer Policy, 19 (3): 271-304.

Goulding, C. (1999) 'Consumer Research, Interpretive Paradigms and Methodological Ambiguities', European Journal of Marketing, 33 (9/10): 859-73.

Hogg, M. and Maclaran, P. (2008) 'Rhetorical issues in writing interpretivist consumer research', Qualitative Market Research: an International Journal, 11 (2): 130-146.

Hollenbeck, C.R. and Zinkhan, G.M. (2006) 'Consumer Activism on the Internet: The Role of Anti-brand Communities', Advances in Consumer Research, 33 (1): 479 - 485.

Ilmonen, K. (1985) 'What Consumer Research Has Forgotten', Journal of Consumer Policy, 8 (4): 415-26.

Jafari, A. (2009) "Forget Me Not": The Researcher's Position in Interpretive Consumer Research. $5^{\text {th }}$ Workshop on Interpretive Consumer Research, Bocconi University School of Management, Milan. 
Jafari, A. (2011) 'Islamic Marketing: insights from a critical perspective', Journal of Islamic Marketing.

Jafari, A. and Goulding, C. (2008) "WWe Are Not Terrorists!" UK Based Iranians, Consumption, and the "Torn Self"'. Consumption, Markets, and Culture, 11 (2): 73-93.

Jafari, A. and Goulding, C. (2010) 'Globalisation Tug-of-War: Consumption as a Site of Conflict', Advances in Consumer Research, 38 (1), First published in 2010 (iFirst).

Jafari, A. and Goulding, C. (forthcoming) 'Globalisation, Reflexivity and the Project of the Self: A Virtual Intercultural Learning Process', Consumption, Markets, and Culture.

Jafari, A., Karababa, E., and Süerdem, A. (2011) Emancipatory Interpretive Consumer Research: "The Road Less Travelled By" in Islamic Societies. 6 ${ }^{\text {th }}$ Workshop on Interpretive Consumer Research. University of Southern Denmark, Odense.

Jafari, A., Maclaran, P. and Taheri, B. (2010) 'The Flow of Cosmetic Routines in Iran', Advances in Consumer Research. 39 (1), First published in 2010 (iFirst).

Joy, A. and Wallendorf, M. (1995) 'Development of Consumer Culture in the Third World: Theories of Globalism and Localism', in R.W. Belk, N. Dholakia and A. Venkatesh (eds.), Consumption and Marketing: Macro Dimensions, pp. 104-142. Cincinatti, OH: Southwestern.

Kancs, D. and Kielyte, J. (2010) 'Education in the East, Emigrating to the West?', European Review, 18 (2): 133-154.

Kernan, J.B. (2002) The Compleat Consumer Researcher. http://www.acr-news.org/WINTR01/WISD.html.

Kozinets, R.V. and Handelman, J.M. (2004) Adversaries of Consumption: Consumer Movements, Activism, and Ideology', Journal of Consumer Research 31(3): 691-704.

Laros, F.J.M., and Steenkamp, J.B.E.M. (2004) 'Importance of Fear in the Case of Genetically Modified Food', Psychology and Marketing, 21(11): 889-908.

Lury, C. (1996) Consumer Culture. Cambridge: Polity Press.

Madhubani, K. (2009) The New Asian Hemisphere: The Irresistible Shift of Global Power to the East. New York: Public Affairs.

McCracken, G. (1988) Culture \& Consumption: Culture and Consumption: New Approaches to the Symbolic Character of Consumer Goods and Activities. Bloomington: Indiana University Press.

Meamber, L.A. and Venkatesh, A. (2000) 'Ethno-consumerist methodology for cultural and cross-cultural consumer research, in S.C. Beckmann and R.H. Elliott (eds). Interpretive consumer research: Paradigms, methodologies and applications, pp. 87-108. Copenhagen, Copenhagen Business School Press.

Romani, S., Hamdi, S., and Dalli, D. (2009) Consumer-Brand Relationships in west Bank: Non-Western Grounded Theory? $5^{\text {th }}$ Workshop on Interpretive Consumer Research, Bocconi University School of Management, Milan.

Said, E. (1978) Orientalism. London: Vintage Books Edition.

Sandelowski, M. (1994) 'Channel of desire: Fetal Ultrasonography in Two Use-Contexts', Qualitative Health Research, 4: 262-80.

Science Metrix (2010) 30 Years in Science: Secular Movements in Science Creation. Available from http://www.science-metrix.com/30years-Paper.pdf.

Slater, D. (1997) Consumer Culture and Modernity. Cambridge: Polity Press.

Steenkamp, J.B.E.M. (2005) A Call for Conducting Global Consumer Research, ACR Doctoral Consortium, Ankara http://www.acrwebsite.org/fop/index.asp?itemID=108. 
Steenkamp J.B.E.M. and Burgess, S.M. (2002) 'Optimum Stimulation Level and Exploratory Consumer Behavior in an Emerging Consumer Market', Future Generation Computer Systems, 19 (2): 131-50.

Tadajewski, M. (2009) 'Editing the History of Marketing Thought', Journal of Historical Research in Marketing, 1 (2): 319-329.

Tadajewski, M. and Saren, M. (2008) 'The past is a foreign country: amnesia and marketing theory', Marketing Theory, 8 (4): 323-38.

Thompson, C.J. and Haytko, D.L (1997) 'Speaking of Fashion: Consumers' Uses of Fashion Discourses and the Appropriation of Countervailing Cultural Meanings', Journal of Consumer Research, 24 (1): 15-42.

UNESCO Science Report

(2010) http://unesdoc.unesco.org/images/0018/001898/189883e.pdf

Varman, R. and Saha, B. (2009) 'Disciplining the discipline: Understanding postcolonial epistemic ideology in marketing', Journal of Marketing Management, 25 (7/8): 811-824.

Venkatesh, A. (1995) 'Ethnoconsumerism: A New Paradigm to Study Cultural and CrossCultural Consumer Behavior', in J.A. Costa and G.J. Bamossy (eds.) Marketing in a multicultural world, pp. 26-67. Thousand Oaks, Sage.

Wolf, E. (1992) Europe and the People without History. Berkeley: University of California Press.

Yazıcıoglu, E.T. and Firat, F. (2007) 'Glocal Rock Festivals as Mirrors to the Future of Culture(s)', in R.W. Belk and J. Sherry (eds), Consumer Culture Theory, Research in Consumer Behavior, Vol. 11, pp. 85-102. Oxford: Elsevier.

Zukin, S., and Maguire, J.S. (2004) 'Consumers and consumption', Annual Review of Sociology, 30: 173-97.

\section{Acknowledgements}

We would like to thank the Association for Consumer Research (ACR) for the partial grant they provided to organise 'The International Workshop on Enhancing the Status of Consumer Research in Non-Western Contexts'. We are also thankful to the Department of Marketing in the University of Strathclyde to partially sponsor the Workshop by providing space and administrative support. Our thanks are extended to Maria Moran, Christine Gray, Alistair Laidlaw and Martin Smith - in the Department of Marketing, University of Strathclyde - for their administrational support in organising the Workshop. We are indebted to Pauline Maclaran for providing us with the opportunity to publish the outcome of the Workshop in Marketing Theory. Also, we would like to thank the following reviewers for their contribution to the special issue: Avi Shankar, University of Bath, UK; Christina Goulding, Coventry University, UK; Dannie Kjeldgaard, University of Southern Denmark, Denmark; Deniz Atik, Izmir University of Economics, Turkey; Douglas Brownlie, University of Stirling, UK; Eminegül Karababa, University of Southern Denmark, Denmark; Güliz Ger, Bilkent University, Turkey; James Fitchett, University of Leicester, UK; Kathy Hamilton, University of Strathclyde, UK; Özlem Sandıkçı, Bilkent University, Turkey; Paul Hewer, University of Strathclyde, UK; Rana Sobh, Qatar University, Qatar; Stephanie O'Donohoe, University of Edinburgh, UK; Taçlı Yazıcıoğlu, Boğaziçi University, Turkey 